\title{
Comparative efficacy of crystalloid and colloid-crystalloid combination for the management of hemorrhagic gastroenteritis in dogs
}

\author{
Chandreyee Sen, Ashwani K. Sharma and P. S. Dhaliwal \\ Department of Veterinary Medicine, Guru Angad Dev Veterinary and Animal Sciences University, Ludhiana, Punjab, India. \\ Corresponding author: Chandreyee Sen, e-mail: chandreyee.sen1710@gmail.com, AKS: ashgadvasu@yahoo.com, \\ PSD: dhaliwalpps@yhoo.com \\ Received: 21-06-2014, Revised: 10-10-2014, Accepted: 16-10-2014, Published Online: 23-12-2014
}

doi: 10.14202/vetworld.2014.1108-1112. How to cite this article: Sen C, Sharma AK, Dhaliwal PS (2014) Comparative efficacy of crystalloid and colloid-crystalloid combination for the management of hemorrhagic gastroenteritis in dogs. Veterinary World 7(12): 1108-1112.

\begin{abstract}
Aim: In the present study, a therapeutic trial was conducted to assess comparative efficacy of crystalloid plus colloid and crystalloid intravenous infusions alone as fluid therapy in dogs suffering from hemorrhagic gastroenteritis (HGE).

Materials and Methods: 20 dogs manifesting HGE, presented at Teaching Veterinary Clinical Services Complex, Ludhiana, Punjab, were selected randomly for the trial. All of them were observed to suffer from moderate dehydration on clinical examination. Crystalloids 5\% DNS and RL were used in combination with polygelin 3.5\% colloidal solution in the first group (Combination I) and in the second group, the afore-said crystalloids (Combination II) were used, both groups consisting of 10 cases each. Antibiotics and symptomatic treatment were same for all the 20 cases. The outcome of both treatment groups was evaluated on hemato-biochemical parameters, before and after administration of the therapies and compared statistically within and between the two groups. Hemato-biochemical parameters of eight clinically healthy animals were considered as control for comparison.
\end{abstract}

Result: On hemato-biochemical examination, significant alterations were observed in leucogram, platelet and serum globulin concentration after the treatment in the first group as compared to before treatment values. In the second group, mean hemoglobin varied significantly after the treatment. After therapies were administered, significant difference in serum globulin level and albumin: Globulin was found in between the treatment groups (Combination I and Combination II). Clinical recovery was faster in the first group than the second group of animals.

Conclusion: On hemodynamic and laboratory data, efficacies of both the fluid therapies were equivocal. Colloidal solutions may hasten recovery in small animals suffering from gastrointestinal crisis.

Keywords: colloid, crystalloid, dog, hemato-biochemical studies, hemorrhagic-gastroenteritis.

\section{Introduction}

In small animal clinics, presentation of patients with vomiting and diarrhea are a day-to-day affair. Hemorrhagic gastroenteritis (HGE), particularly in young dogs is a life-threatening condition due to loss of body fluid and electrolytes along with blood leading to a massive reduction in circulatory volume. This contributes to high mortality associated with the underlying condition and also with concurrent septic complications. Fluid therapy in these patients is essential to correct hypovolemic, dehydration, acid-base imbalances and serum electrolyte abnormalities [1].

Use of various crystalloids in such diseases has been practiced since long. Now-a-days colloid solutions are gaining interest in fluid resuscitation of critically ill patients as they produce immediate circulatory volume expansion, retain longer in the vascular space than crystalloids and have lower risk of tissue edema due to their high molecular weight [2]. Though, relative effectiveness of colloids as compared to crystalloid fluids in reducing mortality is still debatable,

Copyright: The authors. This article is an open access article licensed under the terms of the Creative Commons Attributin License (http:// creative commons.org/licenses/by/2.0) which permits unrestricted use, distribution and reproduction in any medium, provided the work is properly cited. colloids are used alone or in combination widely as are more effective in maintaining colloidal osmotic pressure (COP) [3]. Use of colloidal infusions may provide a more effective fluid management protocol in the crisis of HGE.

Thus, in the present study, a therapeutic trial was conducted to assess comparative efficacy of crystalloid plus colloid and crystalloid intravenous infusions alone as fluid therapy in dogs suffering from HGE.

\section{Materials and Methods}

\section{Ethical approval}

All clinical cases were examined and treated as per standard examination and treatment procedure.

\section{Selection of animals}

A therapeutic trial was conducted on randomly selected 20 cases of HGE manifesting bloody diarrhea which were presented at Small Animal Clinics, Teaching Veterinary Clinical Services Complex (TVCC), Guru Angad Dev Veterinary and Animal Sciences University (GADVASU), Ludhiana, Punjab. All the selected animals were suffering from frequent vomiting and bloody diarrhea. On examination by skin turgidity test, moistness of mucous membrane, capillary refilling time (CRT), mentation of the animals and hemato-biochemical tests, moderate to severe 
dehydration was observed. A group of eight clinically healthy animals were considered as control for this study.

\section{Study design}

The cases were divided into two study groups each consisting of 10 cases. In one group of animals buffered isotonic crystalloid fluids (Ringer's lactate, $5 \%$ dextrose normal saline) were prescribed and in other, colloidal infusion solution along with crystalloids. Amount of crystalloid fluid to be instituted was calculated as, total fluid deficit (in litres) = body weight $(\mathrm{kg}) \times \%$ dehydration. In the other group of animals, colloid was given after initial stabilization with balanced crystalloid infusion. The total volume of crystalloid solutions were infused twice daily in all the cases and were reduced by $25 \%$ in the first group of dogs along with other supportive therapies. Colloidal infusion used in this study was $3.5 \%$ degraded gelatin polypeptides cross-linked via urea bridges (polygelatin), administered at the rate of $10-20 \mathrm{ml} / \mathrm{kg}$ bwt./day [2] with an infusion rate of 50-60 drops/min. The animals were observed closely for any adverse reaction while administration of the colloid and vital signs were monitored. Symptomatic therapies including, antiemetics (metoclopramide hydrochloride and prochlorperazine maleate), $\mathrm{H}_{2}$-antagonist (ranitidine), coagulants (adenochrome monosemicarbazide, ethamsylate) and antibiotic regimen consisting of amikacin sulphate $(10 \mathrm{mg} / \mathrm{kg}$ bwt., $\mathrm{i} / \mathrm{v}$ or $\mathrm{i} / \mathrm{m}, \mathrm{BD})$, ampicillin (20-25 mg/kg bwt., $\mathrm{i} / \mathrm{v}$ or $\mathrm{i} / \mathrm{m}$, BD), metronidazole (15-20 mg/kg bwt., $\mathrm{i} / \mathrm{v}$ or $\mathrm{i} / \mathrm{m}, \mathrm{BD}$ ) were provided to both group of animals [4]. To understand the outcome of therapies administered, clinical and hemato-biochemical parameters were noted in both groups of patients on the day of the presentation and day 6. Hemato-biochemical parameters of the control group dogs were considered as a reference to compare with the after treatment values of diseased animals for assessing improvement towards normalization.

\section{Statistical methodology}

To assess significant heterogeneity, a comparison of hemato-biochemical parameters was done between before- and after therapy-data, that is, on day 0 and day 6 , within each group, by paired-t-test at $95 \%$ confidence level. The outcomes of both the treatment groups were evaluated on day 6 with respect to the control group by one-way analysis of variance at $95 \%$ confidence level with Tukey honestly significantly different and Duncan post-hoc comparison tests.

\section{Results}

Selected dogs were of different breeds, age ranging from 3 to 6 months and of both sexes. They were suffering from frequent vomiting and hematochezia, inappetance or complete anorexia and were recumbent with depressed mentation. On clinical examination of the 20 cases, they were observed to have high rectal temperature (average $103.8^{\circ} \mathrm{F}$ ) and moderate to severe anemia. Skin remained tented for more than $2 \mathrm{~s}$ with sticky gum mucous membrane and CRT more than 2-3 s corresponding to moderate to severe ( $>8 \%$ ) dehydration in the patients. Control animals were of different breeds and of age group 3-5 months. They had normal rectal temperature (average $101.8^{\circ} \mathrm{F}$ ), pale pink conjunctival mucosa, skin turgidity test and CRT within $2 \mathrm{~s}$, normal color and consistency of feces with normal playful activity and appetite. They were regularly dewormed and were vaccinated. Hematobiochemical examination of affected cases revealed percent packed cell volume (PCV): $<0.35 \mathrm{~L} / \mathrm{L}$ and serum biochemistry showed total serum protein: $<55 \mathrm{~g} / \mathrm{L}$ and serum albumin: $<26 \mathrm{~g} / \mathrm{L}$ prior to administration of any therapy, whereas in control group of dogs the values of these parameters were within normal range, that is, $0.409 \pm 0.011 \mathrm{~L} / \mathrm{L}, 64 \pm 2 \mathrm{~g} / \mathrm{L}$ and $32 \pm 1 \mathrm{~g} / \mathrm{L}$ respectively.

\section{Hemato-biochemical studies of the patients treated with Combination I therapy: $(\mathbf{n}=\mathbf{1 0})$}

Anemia was an obvious consequence of HGE along with hypovolemia. Clinically moderate to severe anemia was evident on presentation in all of the cases. On $6^{\text {th }}$ day, average hemoglobin concentration was found $104 \pm 14 \mathrm{~g} / \mathrm{L}$ from $116.3 \pm 5.4 \mathrm{~g} / \mathrm{L}$ of day 0 , though clinical improvement was noticed (Table-1). No significant variation was found in mean PCV while average total erythrocyte count (TEC) was reduced on $6^{\text {th }}$ day significantly $\left(5.76 \pm 0.24\right.$ to $\left.4.78 \pm 0.32 \times 10^{12} \mathrm{~g} / \mathrm{L}\right)$ after the therapy. Mean total leucocyte count (TLC) was found $6.262 \pm 2.657 \times 10^{9} / \mathrm{L}$ before administering therapy that increased to $10,623 \pm 1,832 \times 10^{9} / \mathrm{L}$ after the treatment. In differential leucocytes count, significant $(p<0.05)$ changes were observed, such as percent lymphocytes and platelet count reduced, whereas, neutrophil percentage increased, on day $6^{\text {th }}$ in comparison to day 0 (Table-1).

On 0 day, biochemical examination revealed, mean total protein concentration of $48 \pm 3 \mathrm{~g} / \mathrm{L}$, serum albumin of $23 \pm 2 \mathrm{~g} / \mathrm{L}$ and globulin $26 \pm 2 \mathrm{~g} / \mathrm{L}$ and on $6^{\text {th }}$ day $37 \pm 4.5 \mathrm{~g} / \mathrm{L}, 18.7 \pm 3.6 \mathrm{~g} / \mathrm{L}$ and $18.7 \pm 1.5 \mathrm{~g} / \mathrm{L}$ respectively (Table-1). Hypoproteinemia and hypoalbuminemia seemed to aggravate further on $6^{\text {th }}$ day. Serum globulin reduced significantly on $6^{\text {th }}$ day as compared to day zero (Table-1). Average albumin to globulin ratio was $0.89 \pm 0.09$ and $0.99 \pm 0.16$ respectively on zero and $6^{\text {th }}$ day. Average total bilirubin and alkaline phosphatase (ALKP) concentrations were increased whereas, average serum alanine transaminase (ALT) concentration decreased on day 6 as compared to day 0. Serum blood urea nitrogen (BUN) concentration was observed to reduce considerably on $6^{\text {th }}$ day $(0.499 \pm 0.164 \mathrm{mmol} / \mathrm{L})$ in comparison to that on the 0 day $(3.927 \pm 0.357 \mathrm{mmol} / \mathrm{L})$, whereas, serum concentration of creatinine increased slightly on $6^{\text {th }}$ day. Failed to sustain, three dogs died during the treatment while in one case the owner requested for euthanization. 
Table-1: Hemato-biochemical alterations before and after administering Combination I and Combination II therapy (mean \pm SE).

\begin{tabular}{|c|c|c|c|c|c|c|}
\hline \multirow{2}{*}{$\begin{array}{l}\text { Parameters } \\
\text { (SI units\#) }\end{array}$} & \multicolumn{2}{|c|}{ Combination I } & \multirow{2}{*}{$\begin{array}{c}\text { Significance } \\
\text { P value }\end{array}$} & \multicolumn{2}{|c|}{ Combination II } & \multirow{2}{*}{$\begin{array}{c}\text { Significance } \\
\text { P value }\end{array}$} \\
\hline & Day 0 (before) & Day 6 (after) & & Day 0 (before) & Day 6 (after) & \\
\hline $\mathrm{Hb}(\mathrm{g} / \mathrm{L})$ & $116.3 \pm 5.4$ & $104 \pm 14$ & 0.065 & $121.8 \pm 5.3^{a}$ & $105.2 \pm 4.8^{b}$ & 0.016 \\
\hline TLC $\left(\times 10^{9} / \mathrm{L}\right)$ & $6.262 \pm 2.657$ & $10.623 \pm 1.832$ & 0.191 & $9.630 \pm 2.672$ & $14.233 \pm 3.721$ & 0.336 \\
\hline TEC $\left(\times 10^{12} / \mathrm{L}\right)$ & $5.76 \pm 0.24^{a}$ & $4.78 \pm 0.32^{\mathrm{b}}$ & 0.021 & $5.86 \pm 0.08$ & $5.29 \pm 0.27$ & 0.118 \\
\hline PCV (L/L) & $0.304 \pm 0.015$ & $0.273 \pm 0.029$ & 0.325 & $0.318 \pm 0.024$ & $0.293 \pm 0.013$ & 0.474 \\
\hline Neutrophils \% & $26 \pm 9^{a}$ & $77 \pm 12^{\mathrm{b}}$ & 0.004 & $76 \pm 3$ & $69 \pm 6$ & 0.313 \\
\hline Lymphocytes \% & $33 \pm 9^{a}$ & $23 \pm 11^{b}$ & 0.032 & $22 \pm 3$ & $28 \pm 6$ & 0.377 \\
\hline Eosinophils \% & $2 \pm 1$ & $2 \pm 0.8$ & 0.093 & $2 \pm 1$ & $3 \pm 0.9$ & 0.287 \\
\hline Platelets (×109/L) & $324 \pm 41^{a}$ & $254 \pm 72^{b}$ & 0.039 & $337 \pm 69$ & $354 \pm 93$ & 0.865 \\
\hline Total protein ( $\mathrm{g} / \mathrm{L}$ ) & $48 \pm 3$ & $37 \pm 4.5$ & 0.077 & $48.2 \pm 3.7$ & $48.4 \pm 5.2$ & 0.98 \\
\hline Albumin $(\mathrm{g} / \mathrm{L})$ & $23 \pm 2$ & $18.7 \pm 3.6$ & 0.297 & $20 \pm 1.1$ & $19.7 \pm 2.8$ & 0.913 \\
\hline Globulin ( $\mathrm{g} / \mathrm{L})$ & $26 \pm 2^{\mathrm{a}}$ & $18.7 \pm 1.5^{\mathrm{b}}$ & 0.023 & $28.2 \pm 3.1$ & $28.7 \pm 2.9$ & 0.907 \\
\hline Albumin: globulin & $0.89 \pm 0.09$ & $0.99 \pm 0.16$ & 0.343 & $0.73 \pm 0.06$ & $0.69 \pm 0.08$ & 0.711 \\
\hline BUN (mmol/L) & $3.927 \pm 0.357$ & $0.499 \pm 0.164$ & 0.101 & $11.067 \pm 2.142$ & $4.284 \pm 1.428$ & 0.093 \\
\hline Creatinine $(\mu \mathrm{mol} / \mathrm{L})$ & $35.360 \pm 1.768$ & $44.2 \pm 10.608$ & 0.705 & $74.256 \pm 15.028$ & $35.360 \pm 17.68$ & 0.57 \\
\hline $\operatorname{ALT}(U / L)$ & $19 \pm 1.4$ & $15.5 \pm 1.4$ & 0.058 & $14 \pm 5$ & $7 \pm 2$ & 0.416 \\
\hline Total bilirubin ( $\mu \mathrm{mol} / \mathrm{L})$ & $11.97 \pm 1.37$ & $17.1 \pm 4.79$ & 0.5 & $6.84 \pm 0.51$ & $1.71 \pm 0.17$ & - \\
\hline $\operatorname{ALKP}(U / L)$ & $238 \pm 55$ & $460.5 \pm 214.5$ & 0.776 & $156 \pm 43.1$ & $105 \pm 28.7$ & 0.89 \\
\hline
\end{tabular}

Superscript $a$ and $b$ indicate significant difference between the values of the parameters within the group at $p<0.05$ level, \#SI units are as per serum hematological and biochemical references provided in Merck's Veterinary Manual online (2013). $\mathrm{Hb}=$ Hemoglobin, TLC=Total leucocyte count, TEC=Total erythrocyte count, $\mathrm{PCV}=$ Packed cell volume, $\mathrm{BUN}=$ Blood urea nitrogen, $\mathrm{ALT}=$ Alanine transaminase, $\mathrm{ALKP}=$ Alkaline phosphatase, $\mathrm{SE}=\mathrm{Standard}$ error

\section{Hemato-biochemical studies of the patients treated with Combination II therapy: $(n=10)$}

The average hemoglobin concentration was $121.8 \pm 5.3 \mathrm{~g} / \mathrm{L}$ on presentation which significantly differed on $6^{\text {th }}$ day to $105.2 \pm 4.8 \mathrm{~g} / \mathrm{L}$ after administering combination II therapy (Table-1). However, PCV and TEC were not found altered significantly after the therapy. Mean TLC was found $9.630 \pm 2.672 \times 10^{9} / \mathrm{L}$ on presentation and later became $14.233 \pm 3.721 \times 10^{9} / \mathrm{L}$. No significant change was observed in percent neutrophil, lymphocytes and eosinophil and platelet count (Table-1).

On presentation, biochemical examination revealed, mean total protein concentration of $48.2 \pm 3.7 \mathrm{~g} / \mathrm{L}$, serum albumin of $20 \pm 1.1 \mathrm{~g} / \mathrm{L}$ and globulin $28.2 \pm 3.1 \mathrm{~g} / \mathrm{L}$ and on $6^{\text {th }}$ day $48.4 \pm 5.2 \mathrm{~g} / \mathrm{L}$, $19.7 \pm 2.8 \mathrm{~g} / \mathrm{L}$ and $28.7 \pm 2.9 \mathrm{~g} / \mathrm{L}$ respectively (Table-1). However, there was no significant change in any of the serum biochemical parameters between day 0 and day 6. Average total bilirubin, ALT and ALKP concentration were reduced, indicating improvement of liver function parameters. Concentrations of BUN and creatinine were observed to reduce on $6^{\text {th }}$ day after the treatment. The alterations in total protein, liver and renal function tests observed on day $6^{\text {th }}$ indicated recovery as compared to day 0 , except serum albumin. Three cases succumbed during the treatment and in one case owner did not report back.

\section{Comparison of hemato-biochemical parameters of the patients treated with Combination I and Combination II therapy with control group}

After $6^{\text {th }}$ day of this therapeutic trial, hemato-biochemical parameters of Combination I and II were compared with control animal group which revealed that leucogram (TLC, percent neutrophil, percent lymphocytes) of both the trial groups were improved nearer to control group though hemoglobin and PCV of both the trial groups remained lower than the control animals. Mean total protein and albumin of the trial groups were still lower than the control group and average serum globulin values of Combination I group was lower than that of Combination II group as well as a control group. Accordingly albumin: globulin ratio also altered and was found lower in Combination II group in comparison to other two groups (Table-2).

All the animals were clinically assessed on regular basis and during treatment improvement of the general condition were noticed with increased activity, reduced frequency and volume of vomiting and diarrhea and loss of fluid and blood through feces. Gradual reduction of rectal temperature to an average $102.2^{\circ} \mathrm{F}$, pale to pinkish conjunctival mucous membrane, improved hydration status with CRT $\leq 2$ s and skin turgidity test $<2 \mathrm{~s}$ were observed. Their recovery towards normalization was evident by their interest in food intake when provided with liquid to soft consistency food. Clinical recovery was observed in an average of $4.84 \pm 0.31$ days in animals treated with Combination I while in 6.5 \pm 0.34 days in Combination II group of dogs.

\section{Discussion}

Animals suffering from bloody diarrhoea and vomiting have hypovolemia along with hypoproteinemia and hypoalbuminemia leading to reduction of COP [1,4] of intravascular fluid. Administration of crystalloids alone in combating dehydration in such patients pose risk of low cardiovascular pressure, pooling of water in microvasculature of gut, bacterial translocation, pulmonary and cerebral edema [5-8]. 
Table-2: Comparison of hemato-biochemical alterations after administering combination I and II therapy with control group (mean $\pm \mathrm{SE})$.

\begin{tabular}{|c|c|c|c|c|}
\hline $\begin{array}{l}\text { Parameters } \\
\text { ( SI units\#) }\end{array}$ & Control & $\begin{array}{c}\text { Combination I } \\
\text { (day 6) }\end{array}$ & $\begin{array}{c}\text { Combination II } \\
\text { (day 6) }\end{array}$ & $\begin{array}{c}\text { Significance } \\
\text { (p-value) }\end{array}$ \\
\hline $\mathrm{Hb}(\mathrm{g} / \mathrm{L})$ & $145.8 \pm 2.5^{b}$ & $104 \pm 14^{a}$ & $105.2 \pm 4.8^{a}$ & 0.000 \\
\hline $\operatorname{TLC}\left(\times 10^{9} / \mathrm{L}\right)$ & $16.290 \pm 508$ & $10.623 \pm 1.832$ & $14.233 \pm 3.721$ & 0.152 \\
\hline TEC $\left(\times 10^{12} / \mathrm{L}\right)$ & $6.69 \pm 0.21$ & $4.78 \pm 0.32$ & $5.29 \pm 0.27$ & 0.496 \\
\hline PCV (L/L) & $0.409 \pm 0.011^{\mathrm{b}}$ & $0.273 \pm 0.029^{a}$ & $0.293 \pm 0.0134^{a}$ & 0.000 \\
\hline Neutrophils \% & $75 \pm 3$ & $77 \pm 12$ & $69 \pm 6$ & 0.502 \\
\hline Leucocytes \% & $25 \pm 3$ & $23 \pm 11$ & $28 \pm 6$ & 0.653 \\
\hline Eosinophils \% & $1 \pm 0.4$ & $2 \pm 0.8$ & $3 \pm 0.9$ & 0.102 \\
\hline Platelets $\left(10^{3}\right)$ & $391 \pm 43$ & $254 \pm 72$ & $354 \pm 93$ & 0.265 \\
\hline Total protein ( $\mathrm{g} / \mathrm{L}$ ) & $64 \pm 2^{b}$ & $37 \pm 4.5^{\mathrm{a}}$ & $48.4 \pm 5.2^{\mathrm{a}}$ & 0.000 \\
\hline Albumin $(\mathrm{g} / \mathrm{L})$ & $32 \pm 1^{b}$ & $18.7 \pm 3.6^{\mathrm{a}}$ & $19.7 \pm 2.8^{a}$ & 0.002 \\
\hline Globulin (g/L) & $32 \pm 1^{\mathrm{b}}$ & $18.7 \pm 1.5^{\mathrm{a}}$ & $28.7 \pm 2.9^{b}$ & 0.000 \\
\hline Albumin: globulin & $1.03 \pm 0.07$ & $0.99 \pm 0.16$ & $0.69 \pm 0.08$ & 0.79 \\
\hline BUN (mmol/L) & $5.284 \pm 0.647$ & $0.499 \pm 0.178$ & $5.712 \pm 1.428$ & - \\
\hline Creatinine $(\mu \mathrm{mol} / \mathrm{L})$ & $48.62 \pm 12.37$ & $44.2 \pm 10.608$ & $38.012 \pm 24.752$ & - \\
\hline $\operatorname{ALT}(\mathrm{U} / \mathrm{L})$ & $24.7 \pm 4.4$ & $15.5 \pm 1.4$ & $5.5 \pm 2$ & - \\
\hline Total bilirubin ( $\mu \mathrm{mol} / \mathrm{L})$ & $6.84 \pm 1.88$ & $17.1 \pm 4.788$ & $1.71 \pm 0.171$ & - \\
\hline $\operatorname{ALKP}(U / L)$ & $68.3 \pm 7.9$ & $460.5 \pm 214.5$ & $105 \pm 28.7$ & - \\
\hline
\end{tabular}

Superscript $a$ and $b$ indicate a significant difference among the values of the parameters at $p<0.05$ level; \#SI units are as per serum hematological and biochemical references provided in Merck's Veterinary Manual online (2013). $\mathrm{Hb}=$ hemoglobin; $\mathrm{TLC}=$ Total leucocyte count; $\mathrm{TEC}=$ Total erythrocyte count; $\mathrm{PCV}=$ Packed cell volume; $\mathrm{BUN}=\mathrm{Blood}$ urea nitrogen; $\mathrm{ALT}=\mathrm{Alanine}$ transaminase; $\mathrm{ALKP}=$ Alkaline phosphatase; $\mathrm{SE}=\mathrm{Standard}$ error

Colloidal infusions should be considered in hypovolemic patients when total protein concentration is $<45 \mathrm{~g} / \mathrm{L}$ [1]. Hypoalbuminemia $<20 \mathrm{~g} / \mathrm{L}$ increases mortality in critically ill animals [4]. Colloids provide COP support in vasculature [7] and are effective in diseases with increased microvascular permeability, such as sepsis, systemic inflammatory response syndrome, vascular deficits, pancreatitis, burn, canine parvovirus enteritis etc., [2,4], in low volume resuscitation protocols [2], and can be useful in cases of hypercoagulability, such as viral enteritis [1,9] as they prolong coagulation time. Colloid administration in conjunction with isotonic crystalloids can provide a balance between both type of therapies $[2,8]$ with reduction of volume of crystalloids by $25-60 \%$ to compensate fluid deficit $[10,11]$. In this present study, colloidal infusion was administered in boluses at the dose rate of $10-20 \mathrm{ml} / \mathrm{kg} / \mathrm{day}$ at which chances of adverse effects on coagulation and renal profile are known to be minimum $[8,10,12,13]$.

Colloidal solutions based on $0.9 \%$ saline such as, dextran 70, hydroxyethylstarch, can result in hypercholremic metabolic acidosis $[14,3]$. Newer colloids with balanced electrolytes reduce this complication. Low molecular weight polygelatin 3.5\% exerting COP of $28 \mathrm{~mm}$ of $\mathrm{Hg}$ [15] and osmolarity of $301 \mathrm{com}-$ bined with $145 \mathrm{mmol} / \mathrm{L}$ of $\mathrm{NaCl}, 5.1 \mathrm{mmol} / \mathrm{L}$ of $\mathrm{K}^{+}$, $6.25 \mathrm{mmol} / \mathrm{L}$ of $\mathrm{Ca}^{+2}$ electolytes and pH: $7.3 \pm 0.3$ was used in this present study. Low molecular weight and presence of calcium in this colloidal infusion have less risk of coagulopathy $[16,3]$.

In the present study, clinical assessment of hypovolemia was done on the basis of subjective physical examination variables such as rectal temperature, CRT, mucous membrane, skin fold test, activity and mental status of the animals [8] and hemato-biochemical tests. Prior to the commencement of the therapies, patients had moderate dehydration (8\%), hypoproteinemia and hypoalbuminemia as compared to the clinically healthy animals considered as control. Comparative higher hemoglobin concentration in presence of low PCV on presentation in HGE cases could be due to hemoconcentration that improved later with correction of hypovolemia in both group of animals after therapy. The changes in hydration status and effects of drugs on vital organs of the patients might account for the alterations of parameters of liver and renal panel as observed on day $6^{\text {th }}$ in comparison to day 0 .

After administering Combination I, improvement was observed in the condition with increased activity and appetite, while faster clinical recovery became apparent on successive days than in Combination II group. This was also evident by the fact that, clinical recovery was found to be faster by an average of 1.67 days in the animals treated with Combination I than the ones treated with Combination II. However, there was no other noticeable difference in the hematological and biochemical parameters of Combination I and Combination II therapies. No adverse reactions were noticed during colloidal infusion. Mortality during the treatment had little significance between the two treatment groups. Benefits of crystalloids over colloid solutions or vice-e-versa remain debatable till date [17-20]. Similar, randomized controlled trials on fluid resuscitation and risk of mortality on use of synthetic colloids in critically ill patients as compared with crystalloids were done previously but no statistical evidence of heterogeneity in the trial results of hemato-biochemical variables and length of hospital stay were found $[17,18]$. 


\section{Conclusion}

Most of the meta-analyses regarding inclusion of colloids in fluid resuscitation protocols and recommendations of administration of various colloids are designed for human-patients. Only limited veterinary specific data on effects of various colloids given alone or in combination with isotonic crystalloids on animal physiology, their safety and efficacy in fluid management of critically ill animal patients are available [4]. In this present study, effects of both the fluid therapies on hemodynamic and serological parameters of the animals were ambivalent. However, colloidal infusion might have played an important role in clinical recovery of the animals suffering from gastrointestinal emergencies. Thus the use of different colloids in alleviation of various diseases of animals seeks special attention and need further studies.

\section{Authors' Contributions}

CS conducted the trial, collected samples and analyzed data. AKS planned and monitored the trial and preparation of the manuscript. PSD provided suggestions to improve the trial procedure and manuscript.

\section{Acknowledgments}

The authors are thankful to the Director of Research, In-charge of TVCC and Department of Veterinary Medicine, GADVASU, Ludhiana, Punjab (India) for providing facilities and fund to carry out the present work.

\section{Competing I nterests} interests.

The authors declare that they have no competing

\section{References}

1. Brown, A.J. and Otto, C.M. (2008) Fluid therapy in vomiting and diarrhea. Vet. Clin. North Am. Small, 38(3): 653-675.

2. Mensack, S. (2008) Fluid therapy: Options and rational administration. Vet. Clin. North Am. Small, 38(3): 575-586.

3. Chan, D.L. (2008) Colloids: Current recommendations. Vet. Clin. North Am, Small, 38(3): 587-593.

4. Boag, A. (2013) Managing parvovirus cases. In: $10^{\text {th }}$ Emergency and Critical Care UK Annual Congress, p200-207.

5. Mazzaferro, E.M., Rudloff, E. and Kirby, R. (2002) The role of albumin replacement in the critically ill veterinary patient. J. Vet. Emerg. Crit. Care, 12(2): 113-124.

6. Huges, D. and Boag, A.K. (2011) Fluid therapy with macromolecular plasma volume expanders. In: Di Bartola S.P., editor. Fluid, Electrolyte and Acid-Base Disorders in Small Animal Practice. $4^{\text {th }}$ ed. Saunders, Elsevier, St. Louis, Missouri. p647-664.

7. Chan, D.L., Rozanski, E.A., Freeman, L.M. and Rush JE. (2001) Colloid osmotic pressure in health and disease. Compend, Contin, Educ, Pract., 23: 886-904.

8. Mazzaferro, E. and Powell, L.L. (2013) Fluid therapy for the emergent small animal patient: Crystalloids, colloids, and albumin products. Vet. Clin. North Am. Small, 43(4): 721-374

9. Otto, C.M., Rieser, T.M., Brooks, M.B. and Russell, M.W. (2000) Evidence of hypercoagulability in dogs with parvoviral enteritis. J. Am. Vet. Med. Assoc., 217(10): 1500-1504.

10. Mazzaferro, E.M. (2008) Complications of fluid therapy. Vet. Clin. North Am. Small, 38(3): 670-619.

11. Aiello, S.E. and Moses, M.A., editors, (2013) The fluid resuscitation plan: Emergency medicine and critical care. In: Merck’s Veterinary Manual. http://www.merckmanuals. com/vet/emergency_medicine_and_critical_care/fluid_ therapy/the_fluid_resuscitation_plan.html Accessed on 05-06-2014.

12. Rudloff, E. and Kirby, R. (2013) Colloid fluid therapy. In: Bonagura, J.D. and Twedt, D.C., editors. Current Veterinary Therapy XIV. WB Saunders, Philadelphia, p16-28.

13. DiBartola, S.P., editor. (2011) Fluid, Electrolyte and AcidBase Disorders in Small Animal Practice. $4^{\text {th }}$ ed. Saunders, Elsevier, St. Louis, Missouri.

14. Wilkes, N.J., Woolf R., Mutch, M., Mallett, S.V., Peachey, T., Stephens, R. and Mythen, M.G. (2001) The effects of balanced versus saline-based hetastarch and crystalloid solutions on acid-base and electrolyte status and gastric mucosal perfusion in elderly surgical patients. Anesth. Analg., 93(4): 811-816.

15. Rassam, S.S. and Counsell, D.J. (2005) Perioperative fluid therapy. Contin. Educ. Anaesth. Crit. Care. Pain., 5(5): 161-165.

16. Franz, A., Bräunlich, P., Gamsjäger, T., Felfernig, M., Gustorff, B. and Kozek-Langenecker, S.A. (2001) The effects of hydroxyethyl starches of varying molecular weights on platelet function. Anesth. Analg., 92(6): 1402-1407.

17. Gauthier, V., Holowaychuk, M.K., Kerr, C.L., Bersenas, A.M. and Wood, R.D. (2014) Effect of synthetic colloid administration on hemodynamic and laboratory variables in healthy dogs and dogs with systemic inflammation. J. Vet. Emerg. Crit. Care., 24(3): 251-258.

18. Shahbazi, S., Zeighami, D., Allahyary, E., Alipour, A., Esmaeeli, M.J. and Ghaneie, M. (2011) Effect of colloid versus crystalloid administration of cardiopulmonary bypass prime solution on tissue and organ perfusion. Cell, 98: 9173172580.

19. Roberts, I. and Alderson, P. (2004) Colloids versus crystalloids for fluid resuscitation in critically ill patients. Cochrane Database Syst. Rev., 4.

20. Fisher, M. (2008) Fluids. In: Fink, M., Hayes, M., Soni, N., editors. Classic Papers in Critical Care. $2^{\text {nd }}$ ed. Springer, Oxfordshire, UK. p303. 